\title{
ANALISIS KUALITAS PERAIRAN LAUT TERHADAP AKTIVITAS DI LINGKUNGAN PELABUHAN WAINGAPU- ALOR SUMBA TIMUR
}

\author{
Rikson Siburian', Lisnawaty Simatupang ${ }^{2}$, Minsyahril Bukit ${ }^{3}$ \\ ${ }^{1}$ Jurusan Kimia, Fakultas Matematika Ilmu Pengetahuan Alam Universitas Sumatera Utara, Medan \\ ${ }^{2}$ Fakultas Matematika Ilmu Pengetahuan Alam, Universitas Negeri Medan, Medan \\ ${ }^{3}$ Fakultas Matematika Ilmu Pengetahuan Alam, Universitas Nusa Cendana, Kupang \\ *Penulis korespondensi : riksonsiburian2000@yahoo.com
}

\begin{abstract}
Abstrak
Pelabuhan Kalabahi-Alor di lahan milik PT (persero) pelabuhan Indonesia III Cabang Kupang, dengan luas daerah daratan pelabuhan $71.131 \mathrm{~m}^{2}$ dan lingkungan kerja perairan $1.880 \mathrm{Ha}$. Sedangkan luas lingkungan kepentingan adalah $1.813 \mathrm{Ha}$. Dengan ukuran $4 \times 5$ meter untuk dermaga I dan $115 \times 10$ meter untuk dermaga II. Wilayah monitoring termasuk dalam wilayah Kelurahan Teluk Mutiara, Kecamatan Teluk Mutiara, Kabupaten Alor Provinsi NTT. Kegiatan ini dilakukan untuk analisis monitoring kualitas perairan laut di lingkunganpelabuhan umum KalabahiAlor.Kualitas air meliputi kualitas kimia-fisika perairan laut disekitar pelabuhan. Sampel air laut diambil dari 3 (tiga lokasi) yang berbeda. Hasil analisis dan pemantauan menunjukan bahwa kualitas air laut di kawasan pelabuhan merupakan dampak dari:kegiatan perkapalan (pengoperasian kapal dan kecelakaan kapal), limbah yang berasal dari limbah kapal (bongkar-muat barang), aktivitas pelabuhan lainnya (seperti kegiatan kuliner),saluran drainase yang bermuara kelaut, bocoran dan tumpahan pembongkaran muatan yang bercampur minyak dan oli dari sisa ballast dan air sisa pencucian, serta limbah pemukiman yang masuk secara langsung di pinggiran pelabuhan.Data kualitas (sifat kimia-fisika) air laut wilayah perairan pelabuhan Umum Kalabahi yang dilaksanakan secara analisis insitu maupun laboratorium menunjukkan bahwa seluruh parameter yang diukur masih memenuhi baku mutu yang diizinkan oleh peraturan pemerintah.
\end{abstract}

Kata Kunci: analisis, kualitas air laut, pelabuhan Waingapu

\begin{abstract}
[Sea Water Quality Analysis Of Activities In The Port Of East Sumba Waingapu- Alor] KalabahiAlor port on land owned by PT (Persero), the Indonesian port of Kupang Branch III, with an area of $71131 \mathrm{~m} 2$ area of port land and waters 1,880 Ha working environment. While the broad sphere of interest is 1,813 Ha. With a size of $4 \times 5$ meters to the pier I and $115 \times 10$ meters to dock II. Monitoring region including the Gulf Pearl Village area, Teluk Mutiara, Alor Regency NTT Province. This activity is carried out for the analysis of sea water quality monitoring in the public ports Kalabahi-Alor. The quality of water include chemical-physical quality of the marine waters around the port. Sea water samples taken from 3 (three locations) are different. The results of analysis and monitoring showed that the seawater quality in the port area is the impact of: the activities of shipping (operation of ships and shipwrecks), waste from waste ship (loading and unloading), the activity of other ports (such as culinary activities), drainage channels which empties into the sea, leaks and spills that mixes the unloading of oil and oil from the remaining residual ballast water and washing, as well as residential waste that goes directly on the outskirts of the port. Data quality (chemical-physical) sea water port water area Kalabahi General conducted an in situ and laboratory analysis showed that all the measured parameters still meet quality standards permitted by government regulations.
\end{abstract}

Keyword : analysiss, sea water quality, Waingapu port

\section{Pendahuluan}

Pelabuhan merupakan tempat atau fasilitas jasa untuk melayani kapal yang datang dan pergi di area dermaga, termasuk fasilitas penanganan limbah. Pelabuhan menurut pasal 1 PP Nomor 61 Tahun 2009 tentang Kepelabuhan adalah tempat yang terdiri dari daratan dan perairan di sekitarnya dengan batas batas tertentu sebagai tempat kegiatan pemerintahan dan kegiatan ekonomi yang di pergunakan sebagai 
tempat kapal bersadar, berlabuh, naik turun penumpang dan atau bongkar muat barang yang di lengkapi dengan fasilitas keselamatan pelayaran dan kegiatan penunjang pelabuhan serta sebagai tempat perpindahan intra dan antar moda transportasi (Kementrian Lingkungan Hidup RI, 2009).

Pelabuhan sebagai prasarana angkutan laut memiliki peran strategis menghubungkan pulau dalam kegiatan perdagangan dan angkutan umum lainnya. Saat ini,pelabuhan itu sudah membuktikan diri sebagai gerbang masuk barang - barang kebutuhan pokok yang dikirim dengan petikemas. Secara umum kapal yang berkunjung ke Pelabuhan Kalabahi langsung bersandar di dermaga dengan lama waktu rata - rata kapal general chargo adalah 5 hari, kapal tanker BBM 1 hari dan kapal penumpang selama 3 - 4 jam. Berdasarkan data tercatat rata rata perbulan kunjungan kapal di pelabuhan umum Kalabahi pada tahun 2011 sebanyak 21 unit kapal dan tahun 2012 sebanyak 21 kapal tiap bulan. Sebagai tambahan untuk bulan Oktober 2015trafik kapal berdasarkan pelayaran dan distribusitercatat sebesar 358 unit (385.765 GT).

Hal tersebut tentu akan memberi dapak terhadap ekosistem wilayah pesisir sebagai lokasi flora dan fauna di Pelabuhan Kalabahi - Alor yang bersifat alamiah. Degradasi sumberdaya alam dan keanekaragaman hayati akibat aktivitas kegiatan pelabuhan dapat merubah struktur ekologi pesisir bahkan dapat menurunkan keanekaragaman hayati perairan. Hal ini disebabkan karena pembuangan sampah atau limbah labuh sementara dan sekitar kolam labuh atau dermaga belum diatur.

Pada dasarnya setiap ekosistem alamiah, termasuk di wilayah pesisir memiliki empat fungsi pokok bagi kehidupan manusia, yaitu: i) sebagai penyedia jasa - jasa pendukung kehidupan, ii) sebagai penyedia jasa - jasa kenyamanan, iii) sebagai penyedia sumber daya alam dan, iv) sebagai penerima limbah (Ortolano, 1984). Namun keempat fungsi tersebut memerlukan tiga persyaratan untuk menjamin tercapainya ekosistem yang optimal dan lestrari, yaitu: i) keharmonisan spasial (tata ruang), ii) kapasitas asimilasi dan iii) pemanfaatan berkelanjutan. Studi ini akan lebih lanjut mengkaji persyaratan terkait keharmonisan spasial (tata ruang) pelabuhan dan pemanfaatan berkelanjutan, dengan parameter sumberdaya yaitu kualitas air laut (kimia dan biologi), kualitas udara, sampah dan ruang terbuka hijau(Direktorat Jenderal Perhubungan Laut, 2004).

Walau perkembangan arus barang antar pulau melalui Pelabuhan Kalabahi Alor meningkat terus setiap tahun, akan tetapi perkembangan fisik, prasarana dan sarana Pelabuhan Kalabahi Alor tidak mengalami pertumbuhan secara berarti. Pelabuhan Kalabahi Alor memiliki keterbatasan untuk menampung pertumbuhan arus barang menimbulkan berbagai dampak lingkungan, yaitu dampak fisik ekologi (pencemaran), dampak fisik tanah ruang (ketidaksesuaian pemanfaatan ruang dan kurangnya ruang terbuka hijau), dampak ekonomi dan dampak sosisal (kerawanan sosial dan kekumuhan lingkungan). Dengan kondisi tetap dan terbatasnya area pelabuhan dan kurangnya dukungan fasilitas ditengah semakin meningkatnya arus barang melalui pelabuhan ini, akan menimbulkan turunan dampak terhadap lingkungan hidup, antara lain pencemaran dan ketidaksesuaian pemanfaatan ruang di sekitar lokasi pelabuhan.(Direktorat Pelabuhan dan Pengerukan, Direktorat Jendral. Perhubungan Laut, 2000).

Berdasarkan dokumen evaluasi lingkungan hidup Pelabuhan Kalabahi Alor tahun 2011 menunjukan bahwa di pelabuhan umum Kalabahi Alor untuk kualitas udara, kebisingan, air laut dan biologi sesuai dengan hasil pengukuran pada laboratorium masih dikategorikan dibawah baku mutu lingkungan. Namun mengingat urgensi pelayanan Pelabuhan Kalabahi Alor bagi perekonomian nasional serta untuk mengoptimalisasi fungsi pelabuhan dan mengurangi dampak terhadap ekosistem perairan pesisir Kalabahi Alor secarah terpadu, serta berdasarkan permasalahan permasalahan tersebut di atas, sangat penting untuk melakukan analisis pemantauan lingkungan terhadap kondisi Pelabuhan Kalabahi Alor secara komperensif, sehinga didapatkan alternatif dalam mengoptimalkan fungsi pelabuhan dan mengurangi dampak terhadap lingkungan dan masyarakat.

\section{METODE PELAKSANAAN}

\section{Lokasi Kegiatan dan Waktu Kegiatan}

Lokasi pelabuhan umum Kalabahi-Alor di lahan milik PT pelabuhan Indonesia III (Persero) cabang Kupang, dengan luas daerah lingkungan kerja terdiri dari daerah daratan pelabuhan $71.131 \mathrm{~m}^{2}$ dan daerah lingkungan kerja perairan $1.880 \mathrm{Ha}$. Sedangkan luas daerah lingkungan kepentingan adalah 1.813 Ha. Dengan ukuran dermaga 4 x 5 meter untuk dermaga I dan 115 x 10 meter untuk dermaga II. Wilayah monitoring termasuk dalam wilayah Kelurahan Teluk Mutiara, Kecamatan Teluk Mutiara, Kabupaten Alor Provinsi NTT.Pelaksanaan kegiatan dilakukan pada tanggal 24 Maret 2015 sampai dengan 20 April 2015

\section{Deskripsi Kegiatan}

Kegiatan ini dilakukan untuk analisis monitoring lingkungan perairan terhadap kegiatan yang dilakukan oleh PT pelabuhan Indonesia III(persero) cabang Kupang pada Lokasi pelabuhan umum Kalabahi-Alor.

Adapun kegiatan pengelolaan lingkungan hidup yang dilakukan ditujukan untuk menekan/meminimalkan dampak negatif yang terjadi dan memaksimalkan dampak positif terhadap lingkungan hidup khususnya lingkungan perairan. Pengelolaan dampak lingkungan secara ekologi dimaksudkan untuk mencegah dan menanggulangi dampak melalui : Pemilihan lokasi yang mempunyai dampak minimal dan pemantapan daerah penyanggah untuk menetralisir dampak atau kondisi darurat serta 
rehabilitasi/penghijauan untuk mencegah dan menekan dampak.

\section{Proses Kegiatan}

Merujuk pada dokumen evaluasi lingkungan hidup PT.Pelabuhan Indonesia III(Persero) cabang Tenau Kupang (SK DELH No. Kp. 0503/23.I/P.III2011) tanggal 12 September 2011), terdapat beberapa kegiatan yang telah dan diperkirakan menimbulkan dampak negatif antara lain adalah kualitas air laut. Kualitas air meliputi : (a) padatan tersuspensi, (b) terlarut minyak dan lain-lain.

Sampel air laut diambil dari 3 (tiga lokasi) yakni : A1 = Depan Dermaga PELNI (8013'12.03"S, 124030'59.11'E), A2 = Depan daerah Reklamasi (8013'11.09'S, 124030'53.87'E),

$\mathrm{A} 3$ = Depan Pelabuhan Perikanan ( $8^{0} 13^{\prime} 14.40^{\prime}$, , $124^{0} 31^{\prime} 50.95$ ”E). Gambar satelit lokasi pengambilan sampel dapat dilihat pada gambar 1 di bawah ini. Sedangkan dokumentasi kegiatan pengambilan sampel dapat dilihat pada lampiran 2.

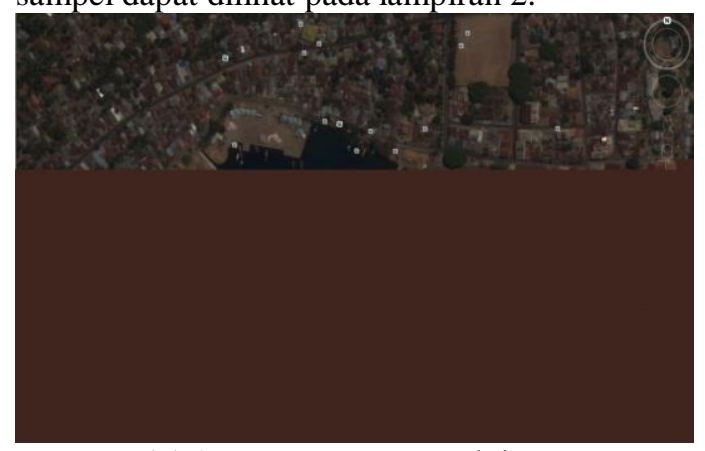

A1 (Depan Dermaga Pelni)

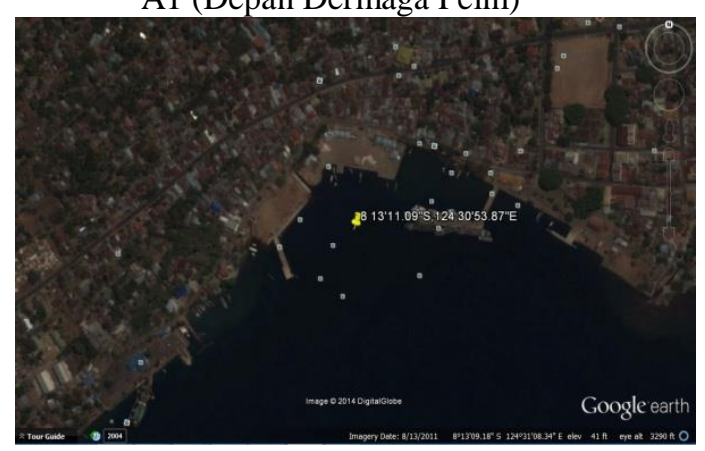

A2 (Depan Reklamasi)

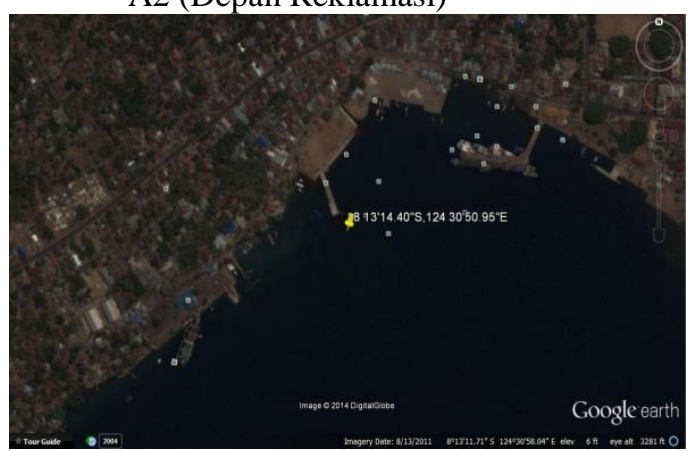

A3 (Pelabuhan Perikanan)

\section{Kualitas Air Laut}

Jenis dampak penting

Jenis dampak penting potensial untuk kualitas air laut adalah menurunnya kualitas kimia-fisika perairan laut disekitar pelabuhan. Pemantauan dan analisis kualitas air yang dilakukan meliputi : (a) padatan tersuspensi, (b) terlarut minyak dan lain-lain. Data kualitas kimia-fisika perairan laut wilayah pelabuhan Umum Kalabahi disajikan dalam Tabel 1dibawah ini.

Data Tabel-1 dan Lampiran-1 menunjukkan bahwa secara umum kualitas air laut dari pelabuhan Kalabahi secara umum masih memenuhi baku mutu air laut yang diperbolehkan oleh peraturan pemerintah. Oleh karena itu, aktivitas di pelabuhan belum berakibat negatif terhadap lingkungan pelabuhan, hanya saja harus ada perhatian khusus terhadap kadar $\mathrm{Fe}$ dan $\mathrm{Pb}$ yang sudah melampaui ambang batas. Perlu adanya pengawasan yang intensif terhadap kapal-kapal yang sandar dan penggunaan bahan bakar oleh kapal-kapal tersebut.

\section{Sumber Dampak Penting}

Sebagai sumber dampak penting terhadap kualitas air laut di kawasan Pelabuhan Umum Kalabahi dapat berasal dari :

a) Limbah dari kegiatan pelabuhan bisa bersal dari limbah kapal (bongkar-muat barang), dan aktifitas lainnya.

b) Bocoran dan tumpahan pembongkaran muatan yang masih bercampur minyak dan oli dari sisa air ballast dan air sisa pencucian.

c) Kegiatan perkapalan (pengoprasian kapal dan kecelakaan kapal)

d) Limbah pemukiman, yang masuk secara langsung di pinggir pantai atau pinggir pelabuhan

e) Dari saluran drainase yang bermuara ke lautvserta dari aliran air hujan

\section{Tolak Ukur Dampak Penting}

Dampak yang tergolong penting dengan tolok ukur tingginya beberapa parameter fisika dan kimia, seperti kandungan logam berat yaitu $\mathrm{Fe}$ dan $\mathrm{Pb}$, padatan tersuspensi, BOD, COD. Bobot dampak dinilai berdasarkan nilai standar Baku Mutu yang tercantum dalam PP Nomor 82 Tahun 2011 tentang pengelolaan kualitas air dan pengendalian pencemaran air.(Kementrian Lingkungan Hidup RI, 2011). 
Tabel 1. Kualitas Kimia-Fisika Air Laut

\begin{tabular}{llllllll}
\hline N & Paramater & Satua & \multicolumn{2}{l}{ Kode Sampel } & & BM & METODE/ \\
o & & n & A1 & A2 & A3 & & ALAT UKUR \\
& Fisik & & & & & & \\
\hline 1 & Suhu & ${ }^{\circ} \mathrm{C}$ & 29,8 & 30,5 & 30,1 & $28-32$ & Thermometer \\
2 & Kekeruhan & NTU & 4,06 & 4,27 & 4,81 & 5 & Turbidimetri \\
3 & Kebauan & - & Alami & Alami & Alami & Alami & Sensorik \\
4 & Padatan Tersuspensi & $\mathrm{mg} / \mathrm{L}$ & 67,94 & 78,68 & 74,48 & 80 & Gravimetri \\
5 & Padatan Terlarut & $\mathrm{mg} / \mathrm{L}$ & 13530 & 18572 & 18091 & - & Gravimetri/Sichi dish \\
& Kimia & & & & & & \\
6 & pH & - & 8,14 & 8,25 & 8,28 & $6,5-8,5$ & Potensiometer \\
7 & BOD & $\mathrm{mg} / \mathrm{L}$ & 2,29 & 2,50 & 1,46 & 20 & Ikubasi $\left(20{ }^{\circ} \mathrm{C}\right)$ \\
8 & Kesadahan total & $\mathrm{mg} / \mathrm{L}$ & 2890,0 & 2790,0 & 2850,0 & - & Titrimetri \\
9 & Oksigen terlarut & $\mathrm{mg} / \mathrm{L}$ & 13,14 & 9,83 & 9,48 & $>5>6$ & Winkler \\
10 & Nitrat-N & $\mathrm{mg} / \mathrm{L}$ & 0,013 & 0,010 & 0,012 & 0,008 & Brucin/Spektrofotometer \\
11 & Minyak \& Lemak & $\mathrm{mg} / \mathrm{L}$ & 138,14 & 136,62 & 164,95 & 1000 & Ekstraksi \\
12 & Salinitas & \%o & 32,68 & 34,4 & 34,7 & $34-35$ & Salinomter \\
13 & Fe & $\mathrm{mg} / \mathrm{L}$ & 1,151 & 1,132 & 1,132 & 1 & AAS \\
14 & Pb & $\mathrm{mg} / \mathrm{L}$ & 1,500 & 0,727 & 0,864 & 0,05 & AAS \\
15 & PCB $\quad$ Poliklor & $\mu \mathrm{g} / \mathrm{L}$ & 0,0054 & 0,0061 & 0,0057 & 0,01 & Kolorimeter/Klorin \\
& bifenil) & & & & & & Pocketester
\end{tabular}

\section{Pengelolaan Dampak Penting}

Pengelolaan dampak terhadap kualitas air laut dapat dilakukan dengan cara :

a) Mencegah kapal-kapal membuang limbah (cair dan padat) yang mengandung bahan B3 diperairan kawasan pelabuhan.

b) Merujuk Kep. MENHUB No. KM-215/AL506/PHB-87, pada kawasan pelabuhan harus tersedia Reception Facilities yang berfungsi sebgai fasilitas penampungan limbah (cair,padat) dari kapal yang mengandung B3, minyak dan sampah.

\section{Jenis Dampak Penting}

Jenis dampak gangguan habitat biota perairan merupakan dampak turunan dari terjadinya dampak penurunan kualitas perairan wilayah pelabuhan Kalabahi.Hal ini akan menyebabkan penurunan komposisi keragaman plankton dan benthos yang berada dalam kawasan perairan pelabuhan, sesuai dengan rantai makanan dalam ekosistem perairan penurunan plankton dan benthos akan mempengaruhi kehidupan ikan dan mengganggu keseimbangan komunitas perairan secara keseluruhan.

\section{Hasil Dan Pembahasan}

Dalam menetapkan kualitas air perlu diketahui parameter-parameter yang dapat memberikan gambaran terhadap kualitas air. Parameter-parameter ini baik secara sendiri-sendiri maupun bergabung dapat memberikan indikasi kualitas air

\section{Sifat fisika air Kebauan}

Hasil pengamatan dan analisis pada 3 (tiga) lokasi pengambilan sampel air laut Pelabuhan Umum Kalabahi menunjukan baik warna, kebauan dan rasa air secara organoleptis memberikan gambaran yang baik, masing-masing terlihat jernih, tidak berbau dan tidak berasa (alami). Lokasi pengambilan sampel masih bersih dari benda-benda terapung, walaupun ada benda terapung masih merupakan benda-benda alami yang berasal dari perairan itu sendiri dan tidak bersifat berbahaya dengan jumlah yang sedikit. Hasil analisis kebauan masih memenuhi baku mutu air laut untuk perairan pelabuhan berdasarkan Lampiran I Surat keputusan Menteri Negara Lingkungan Hidup Nomor 51 Tahun 2004 Tentang Baku Mutu Air Laut, yaitu alami atau tidak berbau.( Kementrian Lingkungan Hidup RI, 2004)

\section{Kekeruhan}

Kekeruhan air umumnya dipengaruhi oleh nilai padatan tersuspensi, semakin tinggi kandungan padatan tersuspensi semakin tinggi pula kekeruhan dan semakin rendah tingkat kecerahan perairan. Hasil analisa kekeruhan pada air laut pada A1 terukur 4,06 NTU, dan pada A2 terukur 4,27 NTU, dan pada A3 terukur 4,81 NTU (Tabel 1 dan Lampiran-1), keadaan ini menunjukan sifat kekeruhan air pada lokasi pengamatan masih di bawah baku mutu yang ditetapkan yaitu 5 NTU.

\section{Zat Padat Tersuspensi (TSS)}

TSS dapat terdiri dari partikel organik, anorganik atau campurannya. Tingginya nilai TSS dalam suatu perairan dapat mempengaruhi kehidupan organisme yang hidup di perairan tersebut, terutama jenis Benthos dan plankton. Hasil pengukuran TSS air Laut Pelabuhan Umum Kalabahi pada A1 terukur $67,94 \mathrm{mg} / \mathrm{l}$, pada A2 terukur 78,68 mg/l, dan pada A3 terukur 74,48 mg/l (Tabel 1 dan Lampiran-1). Hasil dari ketiga pengukuran masih di bawah baku mutu yang ditetapkan yaitu $80 \mathrm{mg} / \mathrm{l}$. 


\section{Zat Padat Terlarut (TDS)}

Hasil pengukuran TDS pada air laut A-1 terukur $13530 \mathrm{mg} / \mathrm{l}$, pada A2 terukur $18572 \mathrm{mg} / \mathrm{l}$, pada A3 terukur $18091 \mathrm{mg} / \mathrm{l}$ (Tabel 1 dan Lampiran1). Nilai tersebut termasuk tinggi jika dibandingkan dengan kualitas air. Hal tersebut, dikarenakan air laut mengandung garam-garam yang menyebabkan tingginya nilai padatan terlarutnya. Berdasarkan hasil pengukuran parameter fisika air laut di beberapa lokasi sampel dapat dinyatakan bahwa kualitas air laut di Pelabuhan Kalabahi-Alor masih memenuhi baku mutu yang ditetapkan oleh pemerintah serta tidak membahayakan ekosistem dan lingkungan perairan.

\section{Suhu}

Suhu merupakan indikator yang penting untuk menentukan efek selanjutnya terhadap nilai parameter air lainnya, seperti mempercepat terjadinya reaksi kimia, reduksi kelarutan gas-gas dalam air atau dapat memperbesar bau atau rasa. Suhu alami untuk perairan tropis yang layak untuk kehidupan organisme berkisar antara $23-32^{\circ} \mathrm{C}$. Hasil pengukuran suhu di lokasi studi berkisar antara $29,8-30,5^{\circ} \mathrm{C}$ dengan rata-rata $30^{\circ} \mathrm{C}$ sedangkan hasil pengukuran suhu air laut Pelabuhan Umum Kalabahi secara langsung di lapangan pada $\mathrm{A} 1$ terukur $29,8^{\circ} \mathrm{C}, \mathrm{A} 2$ terukur $30,5^{\circ} \mathrm{C}$ dan $\mathrm{A} 3$ terukur $30,1^{\circ} \mathrm{C}$ (Tabel 1 dan Lampiran-1). Dari hasil pengukuran masih memenuhi mutu yang ditetapkan yaitu $28-32^{\circ} \mathrm{C}$. Hal ini menunjukan suhu air di lokasi pengamatan tergolong baik dan berada di dalam kisaran suhu air normal yang umumnya terdapat di wilayah perairan.

\section{Sifat Kimia}

Dari hasil analisis parameter kualitas kimia air yang terdapat di lokasi pengamatan, secara umum diketahui kondisi perairan di lokasi masih dalam keadaan baik, masih memiliki kadar yang jauh di bawah standar nilai baku mutu yang telah ditetapkan oleh pemerintah. Parameter kualitas kimia tersebut meliputi :

\section{Derajat Keasaman (pH)}

Derajat keasaman $(\mathrm{pH})$ dapat memberikan gambaran tentang keseimbangan asam dan basa yang secara mutlak ditentukan oleh besarnya konsentrasi ion hidrogen $\left(\mathrm{H}^{+}\right)$dalam perairan. Perairan laut umumnya mempunyai $\mathrm{pH}$ berkisar antara 6,5-9,0. Derajat keasaman sangat penting dalam menentukan nilai guna perairan untuk kehidupan organisme dan keperluan lainnya, umumnya dipengaruhi oleh beberapa faktor seperti aktifitas fotosintesa, suhu dan adanya anion kation. Berubahnya nilai $\mathrm{pH}$ menimbulkan perubahan terhadap keseimbangan kandungan karbon dioksida, bikarbonat dan karbonat di dalam air. Ikan dan biota akuatik lainnya masih dapat mentoleransi lingkungan perairan yang mempenyuai nilai pH antara 4,0-11,0 (Jones, 1964 dan Swingle, 1968). Derajat keasaman $(\mathrm{pH})$ yang ideal untuk kehidupan akuatik adalah berkisar 6,58,5. Hasil pengukuran $\mathrm{pH}$ air Laut Pelabuhan Umum
Kalabahi pada A1 terukur 8,14, pada A2 terukur 8,25dan pada A3 terukur 8,28 (Tabel1 dan Lampiran1). Untuk ketiga lokasi pengambilan sampel $\mathrm{pH}$ masih memenuhi baku mutu yang ditetapkan yaitu 78,5 . Hal ini memberikan gambaran bahwa kondisi perairan tersebut tergolong baik atau netral.

\section{Nitrat $\left(\mathrm{NO}_{3}-\mathrm{N}\right)$}

Analisis kadar $\mathrm{N}-\mathrm{Nitrat}\left(\mathrm{NO}_{3} \mathrm{~N}\right)$ pada air laut A1 terukur $0.013 \mathrm{mg} / \mathrm{l}$ dan pada $\mathrm{A} 2$ terukur 0.010 $\mathrm{mg} / \mathrm{l}$, A3 terukur $0.012 \mathrm{mg} / \mathrm{l}$ (Tabel1dan Lampiran1). Angka tersebut melewati nilai baku mutu yang diperbolehkan menurut peraturan yang berlaku, yakni $0,008 \mathrm{mg} / \mathrm{L}$. Namun masih dapat ditolerasi. $\mathrm{NO}_{3}-\mathrm{N}$ diperlukan dalam metabolism protein, dimana protein tersebut dibutuhkan olehhingga biota air agar bisa hidup dengan baik.

\section{Minyak Dan Lemak}

Parameter minyak dan lemak air Laut Pelabuhan Umum Kalabahi pada A1 terukur 138,14 $\mathrm{mg} / \mathrm{l}$, pada A2 terukur $136,62 \mathrm{mg} / \mathrm{l}$, dan pada A3 terukur 164,95 mg/l (Tabel 1 dan Lampiran-1). Sehingga kadar minyak dan lemak pada daerah sampling masih di bawah baku mutu yang ditetapkan yaitu $1000 \mathrm{mg} / \mathrm{l}$.

\section{Logam Berat Terlarut}

Logam-logam berat dalam air laut secara alami umumnya terdapat dalam jumlah yang rendah, kecenderungan adanya logam berat dalam jumlah yang melampaui batas terutama berasal dari kegiatan ontroposentris (manusia) berupa limbah industri yang masuk ke perairan laut. Hasil pengukuran logam berat terlarut pada perairan air laut Pelabuhan Umum Kalabahi di lokasi pengamatan untuk parameter yang dianalisis menunjukan bahwa kandungan Timbal $(\mathrm{Pb})$ sudah diatas baku mutu yang ditetapkan dan memberikan gambaran bahwa kondisi perairan Pelabuhan Umum Kalabahi perlu diperhatikan lebih baik. Kandungan Timbal $(\mathrm{Pb})$ pada stasiun A1 yakni $1,500 \mathrm{mg} / \mathrm{L}$, A2 yakni $0,727 \mathrm{mg} / \mathrm{L}$, dan untuk A3 adalah $0,864 \mathrm{mg} / \mathrm{L}$. Hasil tersebut menunjukkan bahwa air laut Pelabuhan Umum Kalabahi sudah melampaui baku mutu yang ditetapkan yaitu 0,05 mg/l. Kadar Besi (Fe) pada air laut stasiun A1 terukur 1,151 mg/l, dan pada A2 terukur 1,132 mg/l, sedang pada A3 terukur 1,132 mg/l (Tabel 1 dan Lampiran1), untuk ketiga lokasi pengambilan sampel kadar Besi perlu mendapat perhatian karena sudah melewati baku mutu yang ditetapkan yaitu $1 \mathrm{mg} / \mathrm{l}$.

\section{Salinitas}

Salinitas atau biasa disebut kadar garam atau keragaman ialah jumlah berat semua garam (dalam gram) yang terlarut dalam satu liter air, biasanya dinyatakan dengan satuan permil atau gram per liter. Hasil pengukuran salinitas air laut Pelabuhan Umum Kalabahi pada A1 terukur 32,68\%, pada A2 terukur $34,4 \%$ odan pada A3 terukur 34,7\%o (Tabel 1dan Lampiran-1). Dari hasil pengukuran salinitas masih memenuhi baku mutu yang ditetapkan. Di perairan 
samudra, salinitas biasanya berkisar antara 34-35\%. Di perairan pantai karena terjadi pengenceran, misalnya karena pengaruh aliran sungai, salinitas bisa turun rendah. Hasil pengukuran menunjukan bahwa kisaran salinitas yang didapat dari pengamatan ini masih dalam kisaran nilai toleransi plankton.

\section{BOD (Biologycal Oxigen Demand)}

Kebutuhan oksigen biologis atau lebih dikenal dengan BOD didefinisikan sebagaibanyaknya oksigen yang dibutuhkan oleh mikroorganisme untuk menguraikan bahan organik (carboneous demand) dan senyawa nitrogen (nitrogeneous demand).

BOD pada setiap lokasi pengamatan terukur antara 1$2 \mathrm{mg} / \mathrm{L}$, dengan BOD terendah terdapat pada A3 terukur antara $1,46 \mathrm{mg} / \mathrm{l}$, dan tertinggi pada $\mathrm{A} 2$ yakni 2,50 mg/L, sedangkan pada A1 terukur 2,29 mg/L (Tabel 1 dan Lampiran-1). Perairan yang mengandung BOD lebih dari $10 \mathrm{mg} / \mathrm{L}$ berarti perairan tersebut telah tercemar oleh bahan organik, sedangkan apabila dibawah $3 \mathrm{mg} / \mathrm{L}$ berarti perairan tersebut masih cukup bersih(Lee et.al (1978)).

\section{Oksigen Terlarut}

Oksigen terlarut merupakan variabel kimia yang mempunyai peranan yang sangat penting bagi kehidupan biota air sekaligus menjadi faktor pembatas bagi kehidupan biota. Daya larut oksigen dapat berkurang disebabkan naiknya suhu air dan meningkatnya salinitas. Konsentrasi oksigen terlarut dipengaruhi oleh proses respirasi biota air dan proses dekomposisi bahan organik oleh mikroba. Pengaruh ekologi lain yang menyebabkan konsentrasi oksigen terlarut menurun adalah penambahan zat organik (buangan organik) (Connel dan Miller, 1995). Oksigen terlarut di A1 terukur 13,14 mg/l, di A2 terukur 9,83 mg/l, dan di A3 terukur 9,48 mg/l (Tabel 1dan Lampiran-1).Ketiga lokasi ini masih sesuai baku mutu menurut Keputusan Menteri Negara Lingkungan Hidup No. 51 tahun 2004 Tentang Baku Mutu Air Laut yaitu $>5>6$. Menurut Trihadiningrum dan Sudaryati (1996), dalam Wijayanti 2007) bahwa perairan yang memiliki kadar oksigen rendah hanya dapat dihuni oleh benthos dari kelas Oligochaeta yang tahan terhadap kadar oksigen rendah. Hal ini menjadikan oksigen sebagai faktor pembatas dalam perairan.

\section{Kesadahan}

Hasil analisa Kesadahan air laut Pelabuhan Umum Kalabahi pada A1 terukur $2890 \mathrm{mg} / \mathrm{L}$ dan pada A2 terukur $2790 \mathrm{mg} / \mathrm{L}$, dan pada A3 terukur $2850 \mathrm{mg} / \mathrm{L}$. Hasil ini menunjukkan adanya perbedaan kandungan kimia dari masing-masing lokasi sampel. Namun demikian, hasil kesadahan tidak jauh berbeda. Artinya, kandungan kimia didalam perairan relatif homogen di berbagai titik. Hasil analisis kesadahan masih memenuhi baku mutu air laut untuk perairan pelabuhan berdasarkan Lampiran I Surat keputusan Menteri Negara Lingkungan Hidup Nomor 51 Tahun 2004 Tentang Baku Mutu Air Laut, yaitu alami atau tidak berbau.( Kementrian Lingkungan Hidup RI, 2004)

\section{PBC (Poliklor bifenil)}

Hasil analisa nilai PBC air laut Pelabuhan Umum Kalabahi pada A1 sebesar 0,0054 $\mu \mathrm{g} / \mathrm{L}, \mathrm{A} 2$ sebesar 0,0061 $\mu \mathrm{g} / \mathrm{L}$ dan pada A3 sebesar 0,0057 $\mu \mathrm{g} / \mathrm{L}$. Nilai ini masih memenuhi standar baku mutu yang ditetapkan yaitu sebesar $0,01 \mu \mathrm{g} / \mathrm{L}$.

\section{Kesimpulan}

1. Pemantauan lingkungan perairan di wilayah Pelabuhan Kalabahi terhadap air laut (sifat fisikakimia) yang dilaksanakan secara analisis insitu maupun laboratorium menunjukkan bahwa seluruh parameter yang diukur masih memenuhi baku mutu yang diizinkan oleh peraturan pemerintah.

2. Kegiatan yang menjadi sumber dampak terhadapkualitas air laut di kawasan Pelabuhan Kalabahi dapat berasal dari:

a) Kegiatan perkapalan (pengoperasian kapal dan kecelakaan kapal).

b) Limbah dari kegiatan pelabuhan bisa berasal dari limbah kapal (bongkar-muat barang), dan aktivitas pelabuhan lainnya (seperti kegiatan kuliner).

c) Dari saluran drainase yang bermuara kelaut serta dari aliran air hujan.

d) Bocoran dan tumpahan pembongkaran muatan yang masih bercampur minyak dan oli dari sisa ballast dan air sisa pencucian.

e) Limbah pemukiman yang masuk secara langsung di pinggiran pantai atau pinggiran pelabuhan.

3.Melalui kegiatan ini dapat memberikan masukan bagi Pelindo sebagai administrator pelabuhan tentang kondisi terkini lingkungan perairan di wilayah administrasi mereka untuk membenahi kegiatan pelabuhan sehingga mengurangi/ lebih meminimalisasi dampak limbah yang dihasilkan terhadap lingkungan perairan.

\section{Daftar Pustaka}

Connel, D. W. dan Miller, G. J. 1995.

Kimia dan Otoksikologi Pencemaran.

Cetakan Pertama. Jakarta: Universitas Indonesia.

Direktorat Pelabuhan dan Pengerukan, Direktorat Jendral. Perhubungan Laut, 2000. Pedoman Pembangunan Pelabuhan ( Terjemahan dari Port Development Handbook, UNCTAD ) Depertemen perhubungan, Jakarta.

Direktorat Jenderal Perhubungan Laut, 2004. Pedoman Teknis Pelabuhan Berwawasan Lingkungan ( Ecoport ), Depertemen Perhubungan, Jakarta.

Jones R. 1976. Mesh regulation in the demersal 
fisheries of the South China Sea area. Manila: South China Sea Fisheries Development and Coordinating Programme. SCS/76/WP/34 : $75 p$

Kementrian Lingkungan Hidup RI, 2004. Keputusan. MenLH No 51/2004 tentang Bahan Mutu Air Laut, Jakarta.

Kementrian Lingkungan Hidup RI, 2009. Keputusan Menteri Negara Lingkungan Hidup No. 5 tahun 2009 tentang Pengelolaan Limbah di Pelabuhan, Jakarta.

Kementrian Lingkungan Hidup RI, 2011. Peraturan Pemerintahan RI No. 82/2011 tentang Pengelolaan Kualitas Air dan Pengendalian Pencemaran air, Jakarta.

Lee CD, Wang SB dan Kuo CL. 1978. Benthic Macroinvertebrate and Fish as Biological Indicators of Water Quality, With Reference of Community Diversity Index. Bangkok. International Conference on Water Pollution Control in Development Countries.
Ortolano, L, 1984, ENVIRONMENTAL PLANNING AND DECISION MAKING, John Wiley and Sons, New York.

Swingle HS. 1968. Standarization of chemical analysis for water pond muds. FAO Fisheries 44(4)

Wijayanti.H. 2007. Kajian Kualitas Perairan Di Pantai Kota Bandar Lampung Berdasarkan Komunitas Hewan 16Makrobenthos. Tesis Universitas Diponegoro Semarang

\section{Lampiran-1 Hasil Analisis Air}

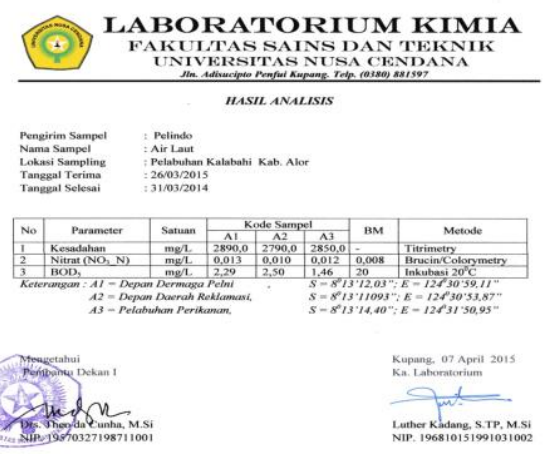

\section{Lampiran-1. Hasil Analisis Air}
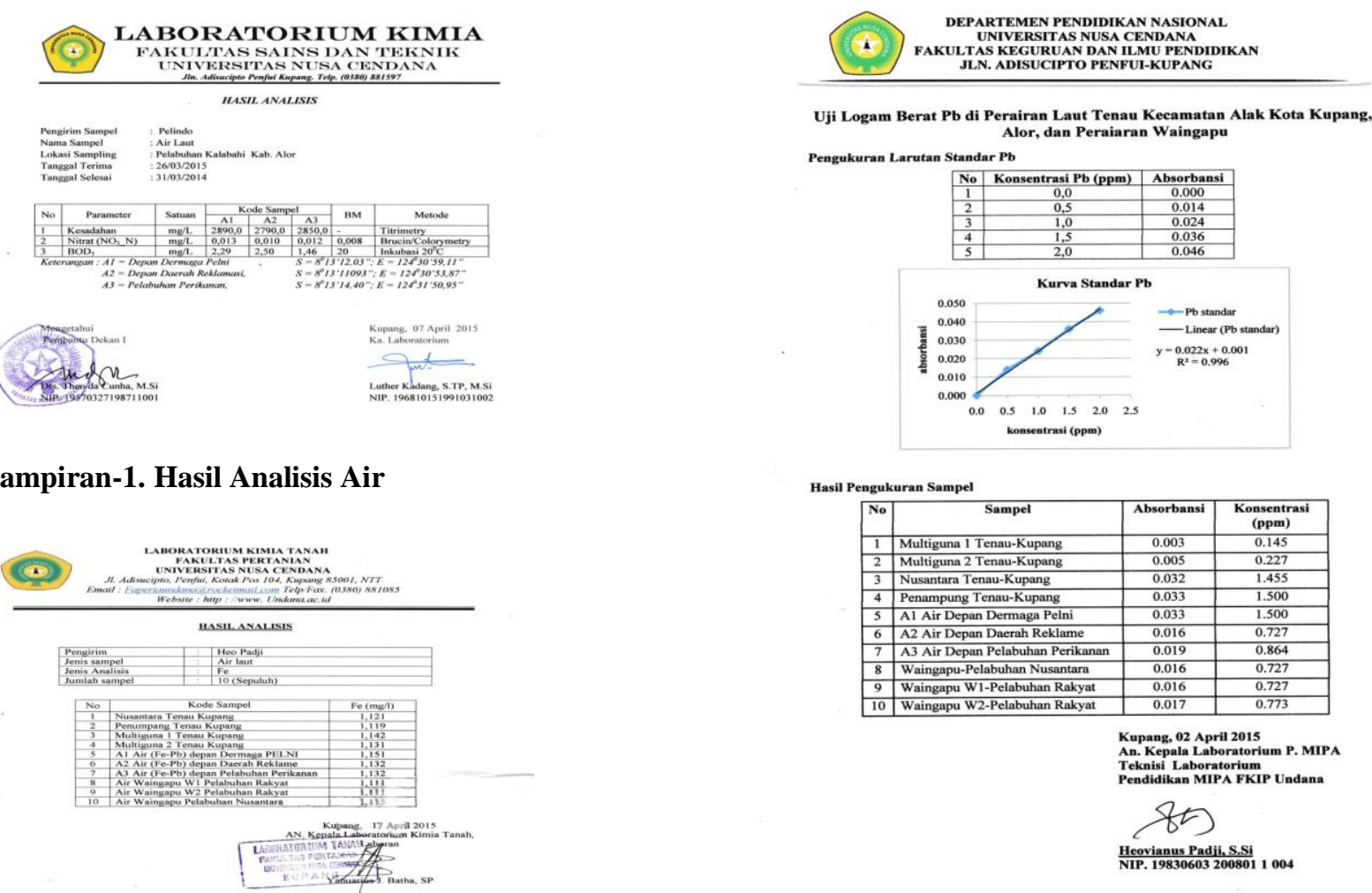

Lampiran-2 Dokumentasi Kegiatan

\section{Lampiran-1 Hasil Analisis Air}



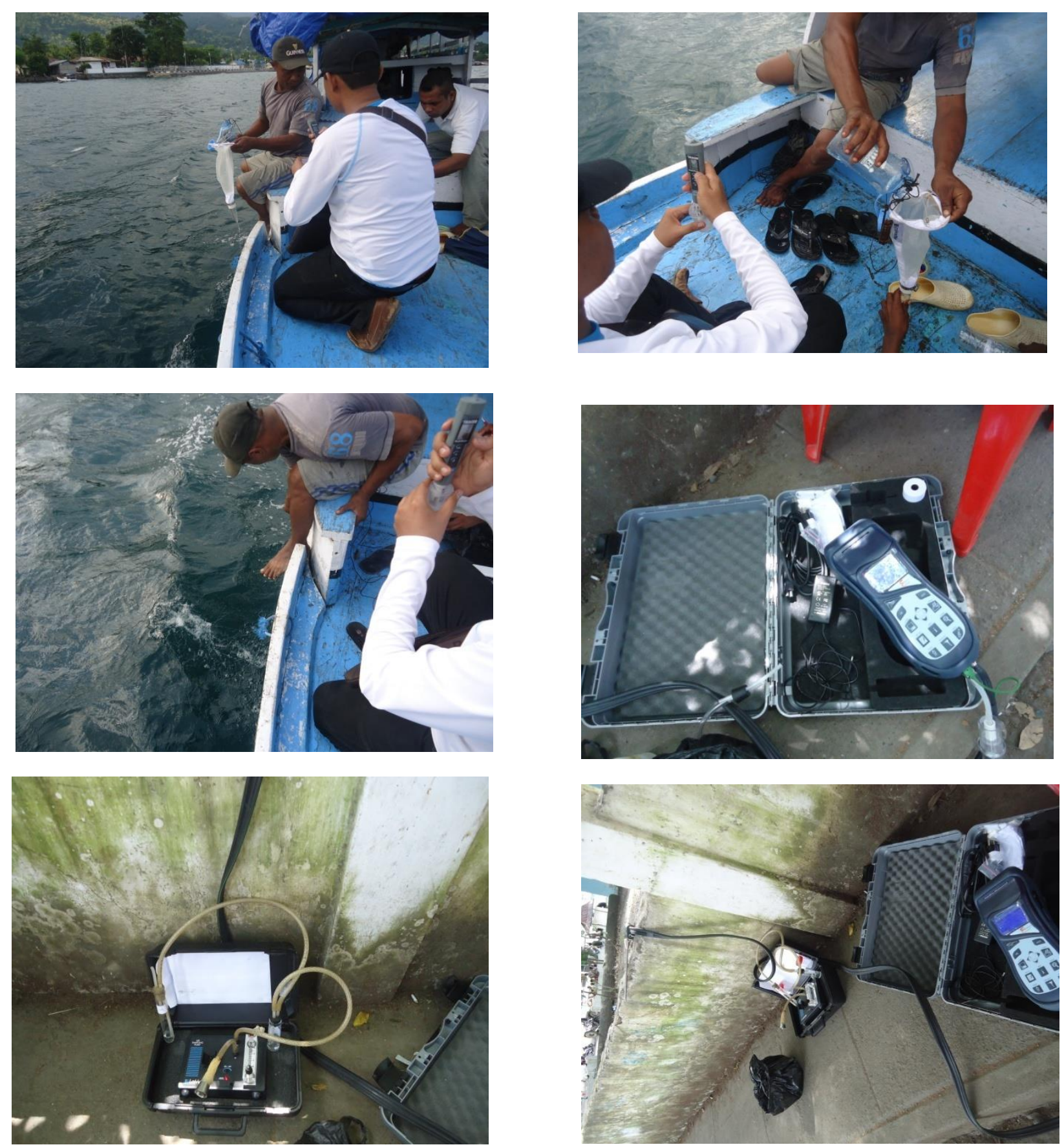